\title{
Consumer Protection Due to Snacks Consumption Containing Food Additives
}

\author{
Endang Sutrisno ${ }^{1}$, Heryani Agustina ${ }^{2}$, Ayih Sutarih $^{3}$, Nur Ika Sofiyanti ${ }^{4}$ \\ \{pascaunswagati16@gmail.com ${ }^{1}$, endangsutrisno94@gmail.com ${ }^{1}$ \} \\ ${ }^{1,2,3,4}$ Postgraduate in Law and Law Faculty of University of Swadaya Gunung Jati Cirebon, West Java \\ Terusan Pemuda No.1A By Pass telp. (0231) 488924 Ext.64 Fax.(0231) 488924
}

\begin{abstract}
This research is a non-doctrinal study with a socio-legal studies approach. The research findings that the role of the Regional Government of Tegal Regency to supervise food containing dangerous Food Additives and exceed the maximum limit by periodically assigning employees from the field of inspection and investigation to traditional markets, supermarkets, factories or home industries, traders for food samples that are detected contain Food Additives that are not in accordance with the applied regulations, then testing will be carried out in the laboratory. And the public's legal awareness of the use of Food Additives in school children's snacks is still lacking due to the low level of public knowledge about food quality and safety, real action is needed in the form of government policy from the Tegal Regency Regional Government to supervise and provide strict sanctions for those who violate law, and provided health education both formally and informally.
\end{abstract}

Keywords: Consumer Protection, Food Additives, Regional Government of Tegal Regency.

\section{Introduction}

The globalization era of economic development, especially in the fields of industry and national trade now, has produced various forms of goods and services that can be consumed [1]. This condition on the one hand benefits consumers, because the consumer needs for the desired goods and services can be fulfilled, and the wider the freedom of consumers to choose various types and quality of goods and services in accordance with the ability of consumers [2], [3]. This condition results in the position of consumers with business actors being unbalanced and consumers are in a weak position. Consumers only become objects that do not have independent power to weigh an item or service. When you find a problem, consumers are usually just silent. Meanwhile, business actors know more precisely the situations, conditions and quality of the goods produced.

The existence of a city in Indonesia caused by the impact of development has required the city to fulfill the interests of people's development [4]-[6]. The conflict of new values has affected the lives of the people. Confrontation of the traditional norms with modern norms results in reality at the intersection of norm encounters; communities lose their basis foundation to undergo the development process, while the modern norms are not fully accepted as guidance for the development process. 
Low public knowledge about food quality and safety leads to widespread cases of food poisoning and violations of consumer rights [3], [7]-[9]. This is also compounded by various types of Food Additives sourced from chemical compound products and derivatives such as formalin, borax, textile dyes and others without regard to the dose or threshold and the danger posed by these chemicals to consumers.

Legal protection given to consumers for consumer goods containing hazardous chemicals contained in Act No. 8 of 1999 on consumer protection. The existence of Law No. 8 of 1999 on Consumer Protection, it is hoped that consumer protection efforts in Indonesia can be increased so that consumers are not always in a weak position and businesses can also improve the quality of products offered to consumers [5], [10].

Violations in the use of Food Additives can be dangerous, these actions must be prevented and acted decisively by the government which has an obligation to protect its people from the use of Food Additives that are not in accordance with regulations. Food security policy and national nutrition development are part of national food policy including the use of Food Additives. Based on this, the question is how is the legal protection of the health of school children as a result of consuming snacks that contain dangerous Food Additives and how is the community's legal awareness in the use of Food Additives.

\section{Research Method}

This research uses a socio-legal studies approach to study community's legal understanding of consumer protection in the use of Food Additives in school children's snacks. This type of research is qualitative research that emphasizes the nature of socially constructed reality in the issue of consumer protection related to the use of Food Additives in School Children Snack Food. The data obtained in this study are primary data obtained through observation and interviews and secondary data in the form of legislation, books, journals and other data that supports this research [11]-[13].

\section{Result and Discussion}

The right to child health is a part of human rights that must be guaranteed, protected, and fulfilled by parents, family, society and the Government. Article 28B of the 1945 Republic of Indonesia Constitution stipulates, among others, that every child has the right to survival, growth and development. Legislation and policies to protect children's health, among others, First, Act Number 36 of 2009 on Health. Article 79 regulates that school health is carried out to improve students' healthy living skills in a healthy environment so that students can learn, grow and develop harmoniously and as high as possible into quality human resources. Furthermore, Article 141 stipulates that the Government, Regional Government, and / or the community together guarantee the availability of food which has high nutritional value evenly and affordable. Second, Act Number 23 of 2002 on Child Protection, in Article 45, among others, regulates the responsibility of parents and families to maintain children's health. When children enter school age, they do not yet have sufficient knowledge about how to recognize clean and healthy food and drinks, so the role of parents and families to monitor food consumed by children is a necessity. 
Third, Act Number 20 of 2003 on the National Education System, the national education goal, among others, to develop the potential of students to become human beings who believe and fear the Almighty God, have a noble, healthy, and knowledgeable character. One effort to realize healthy students, stipulated Government Regulation Number 19 of 2005 on National Standards of Education, in Article 42 paragraph (2) regulates about each education unit, among others is obliged to have a canteen room.

Fourth, Act Number 18 of 2012 concerning Food. The purpose of organizing food is to facilitate or increase access to food for the community, especially the people who are most easily experiencing health problems or malnutrition.

The results of the research obtained in the field by conducting interviews with traders and students of SDN Slawi Kulon 03 and SDN Slawi Wetan 01, SDN Slawi Wetan 02, SDN 01 Kalibakung, SDN 01 Bojong explained that supervision was carried out by the Tegal District Health Office through Sanitation of school snacks Inspection every month. Supervision by the Tegal District Health Office also examines hygiene factors for goods and snacks itself. Supervision is carried out every three months to all schools. Other types of supervision are in the form of mobile laboratory which is carried out every one (1) year throughout the schools. If there is a positive snack containing hazardous materials, the merchants who sell the snack will be given more intensive guidance.

The protection provided by the Tegal District Health Office is in the form of guidance to traders every (3) three months, by gathering all traders and providing information on various types of hazardous materials, the difference of food that is containing hazardous ingredients and the food that is not, and explaining the dangers of consuming food containing ingredients dangerous, explains how to produce processed food that is good and explains the hygiene of an item. Counseling is done by collecting traders and explained in a certain place. If there are positive traders selling School Children Snack Food containing dangerous ingredients, they will be given more intensive guidance.

Legal protection to consumers given by the DinKes of Tegal Regency is limited to supervision and guidance to traders so as to minimize the possibility of unsafe School Children Snack Food. Supervision of School Children Snack Food conducted by the Tegal District Health Office on traders by conducting snacks sampling which is thought to contain hazardous materials and then do laboratory tests, if the School Children Snack Food contains hazardous ingredients such as borax, formalin, rodhamin B and methanyl yellow. Supervision carried out by the Distric Health Office also examined hygiene factors for an item and the Snack Food itself. Supervision is carried out every month throughout the schools with the help of the School Health Unit in every school to always supervise School Children Snack Food which is thought to contain dangerous ingredients. Supervision carried out by the health office is not only for traders in the school environment, but traders outside the school are also given supervision and guidance. The protection provided by the Tegal District Health Office is in the form of guidance to traders every (2) twice in one (1) year.

Legal protection for consumers is not only provided by the Tegal District Health Office but the school, the principal and teachers also participate in providing protection in the form of monitoring school children snacks that are traded in the school environment, monitoring is carried out by the school and the School Health Unit of each school by asking traders who sell snacks that they must have the results of the last laboratory examination. Another effort in supervision carried out by the school was by asking the Health Office to take snacks that were traded to be tested for laboratory and microbiological tests. The school also prohibits school children from buying snacks outside the school area. In fact there are still many less hygienic foods that are still sold in the community. Children as consumers of School Children Food 
Snacks are weak because children as consumers still do not know Snack Food that is safe for consumption. The weakness of children as consumers greatly influences the insight into safe food and affects the health of the child itself when consuming unsafe school children snacks.

This training is held every twice in 1 (one) year. Coaching is done so that all traders know the importance of maintaining the cleanliness of cutlery and using nutritious and good quality food ingredients. Coaching conducted by the Tegal District Health Office needs to be intensified again because in reality in the field at 2 elementary schoolls namely SDN Slawi Kulon 03 and SDN Wetan 01 which have been studied there are still traders who do not know the rules for prohibiting the provision of Food Additives on food traded, do not know how to produce processed foods that are good and maintain cleanliness of food equipment to remain hygienic. Legal awareness is a community's perspective on the law, what should be done and not done by law, and respect for the rights of others (tolerance). This means that in legal awareness it contains tolerance. Regarding the use of Food Additives by snacks sellers in school children, the legal awareness in making or selling snacks is that does not contain dangerous ingredients in the form of borax, formalin, Rhodamin B and methanyl yellow. If the hazardous material has been mixed in food in the production process, the food is very dangerous if it is consumed and in the long term it will cause cancer if the food is consumed. [5] Law enforcement refers to implementing the textual of legal norms in the social realities of society. The contens of the substance of the norm is hoped to be clarified through legal behavior so that questions about legal awareness, legal compliance, legal feelings, legal attitude will be more prominent.

Legal awareness essentially is not awareness of the law, but mainly is the awareness of the existence or occurrence of "legal action" or "onrecht". Indeed, the fact is that legal awareness is just being questioned or talked about and stirred up in the mass media if legal awareness is declining or absent, if there is a violation of law. [6] The law is the crystallization of the values contained in society is certain, however, in law the values are usually described as pairs, but not infrequently arguing. These values, for example order and peace, legal certainty and comparability, public interest and individual interests. The absence of harmony and harmonization between these values described in the community will certainly disrupt the purpose and course of the law enforcement process. [7] The government must be able to give affirmation to the community, the law that is made leads to the interests of the community and oriented towards social justice.

[8] Law is an important element in the development of politics and it makes the relationship with government policy clearer. Through legislation, the Government determines what it can do and what not to do. Law defined as legislation is a system of norms where the rule of law is arranged in unity within a hierarchical manner. The lower legal norms should not be contradictory to the higher legal norms. Increasing legal awareness of the community can basically be done in two ways, namely in the form of action (action) and education (education). Here's the explanation : First, action, the act of legal awareness of the community can be done in the form of drastic action, by aggravating the threat of punishment or by further tightening the supervision of the obedience of citizens to the law. This method is incidental and shocking and is not an appropriate measure to increase community legal awareness. Second, education, education can be done both formally and informally. Things that need to be considered and instilled in formal/non-formal education are basically about how to become good citizens, about what are the rights and obligations of a citizen. Instilling legal awareness means instilling cultural values. And cultural values can be achieved by education. Therefore, after knowing the possible causes of the decline in public legal awareness, effective and efficient coaching efforts are by education. 


\section{Conclusion}

Legal protection for consumers, every food product, especially food, must follow food safety and quality standards. As stated in article 111 of Act No. 36 of 2009 concerning health, food and beverages used for the community must be based on health standards and / or requirements, and can only be circulated after obtaining distribution permits in accordance with the provisions of the legislation, namely the obligation of business actors to have good intentions in carrying out their business activities. The role of the Tegal regency government in supervising food containing dangerous food additives and exceeding the maximum limit is by periodically assigning employees from the field of inspection and investigation to traditional markets, supermarkets, factories or home industries, traders for taking food samples detected contain food additives that are not in accordance with the regulations, which will then be tested in the laboratory. As well as destroying the food if from the results of the inspection, the food contains food additives that are dangerous or not in accordance with the regulations. Community legal awareness of the use of Food Additives in School Children Snacks is still lacking due to the low level of public knowledge about food quality and safety causing widespread food poisoning and violations of consumer rights, which is also compounded by various types of Food Additives sourced from chemical compound products and its derivatives, so that action is needed from the Regional Government of Tegal Regency to carry out supervision and provide strict sanctions for those who violate, and provide health education both formally and formally.

\section{References}

[1] N. H. T. Siahaan, A. Sudirman, and Y. W. Nugroho, Hukum konsumen: perlindungan konsumen dan tanggungjawab produk. Panta Rei, 2005.

[2] M.-F. Chen, "Consumer attitudes and purchase intentions in relation to organic foods in Taiwan: Moderating effects of food-related personality traits," Food Qual. Prefer., vol. 18, no. 7, pp. 1008-1021, 2007.

[3] A. Nasution, Hukum perlindungan konsumen: Suatu pengantar. Diadit Media, 2002.

[4] E. Sutrisno, "Relations between Legal Culture and Economic Empowerment among Marginalized Group of Farmers," J. Leg. Ethical Regul. Issues, 2019.

[5] Y. Shofie, Perlindungan Konsumen dan Instrumen-instrumen hukumnya. Citra Aditya Bakti, 2000.

[6] E. Sutrisno, "Bunga Rampai: Hukum Dan Globalisasi, Yogyakarta." Genta Press, 2007.

[7] A. N. N. M. REES, "Factors influencing consumer choice," Int. J. Dairy Technol., vol. 45, no. 4, pp. 112-116, 1992.

[8] S.-M. Shim, S. H. Seo, Y. Lee, G.-I. Moon, M.-S. Kim, and J.-H. Park, "Consumers' knowledge and safety perceptions of food additives: Evaluation on the effectiveness of transmitting information on preservatives," Food Control, vol. 22, no. 7, pp. 1054 $1060,2011$.

[9] M. Carocho, P. Morales, and I. C. F. R. Ferreira, "Natural food additives: Quo vadis?," Trends Food Sci. Technol., vol. 45, no. 2, pp. 284-295, 2015.

[10] L. A. F. Ekaningsih et al., "Effect of Net Income, CSR Disclosure, Corporate Profitability Against Abnormal Return on the Indonesia Stock Exchange," in Journal of Physics: Conference Series, 2019, vol. 1175, no. 1, p. 12289.

[11] D. Bandung, "Metode Penelitian Pendidikan Pendekatan Kuantitatif, Kualitatif dan R \& D," Bandung Alf., 2013. 
[12] P. Sugiyono, "Metode Penelitian Kuantitatif, Kualitatif, dan R\&D," Metod. Penelit. Kuantitatif, Kualitatif, dan R\&D. Bandung CV Alf., 2010.

[13] S. Azwar, "Metode Penelitian; Penelitian Sebagai Kegiatan Ilmiah," Yogyakarta: Pustaka Belajar, 1999. 